\title{
DETECÇÃO DE Escherichia coli ENTEROPATOGÊNICA (EPEC) E SHIGATOXIGÊNICA (STEC) EM GALINHAS CAIPIRAS NA REGIÃO DE RIBEIRÃO PRETO - SP
}

\author{
DETECTION OF ENTEROPATHOGENIC (EPEC) AND SHIGATOXIGENIC \\ (STEC) Escherichia coli IN BACKYARD CHICKENS IN THE REGION OF RIBEIRÃO \\ PRETO - SP
}

M. M. BORZI ${ }^{1 *}$, E. S. OLIVEIRA ${ }^{1}$, M. V. CARDOZO ${ }^{1}$, F. A. ÁVILA ${ }^{1}$

\section{RESUMO $^{1}$}

A enterobactéria Escherichia coli está entre os principais agentes causadores de perdas econômicas na avicultura, vinculada diretamente à maneira e ao ambiente como as aves são criadas, podendo causar infecções nas próprias aves como também nos seres humanos. Os patótipos de $E$. coli enteropatogênica (EPEC) e shigatoxigênica (STEC) constituem patógenos de importância na saúde pública pelo potencial de transmissão na forma de doenças entéricas ao homem e pela possível emergência de isolados multirresistentes. Baseado nisso, o presente estudo teve como objetivo verificar a prevalência dos genes eae, stx1 e stx2, característicos destes dois patótipos em amostras de galinhas caipiras na região de Ribeirão Preto SP. Para tanto, foram coletadas com auxílio de suabe amostras de fezes de 80 galinhas caipiras e estas foram submetidas a uma triagem por triplex-PCR para a deteç̧ão de STEC e EPEC. O programa de amplificação gênica constituiu de um primeiro ciclo a $95^{\circ} \mathrm{C}$ por 2 minutos, seguido de outros 25 ciclos, cada constituído por três passos $\left(94^{\circ} \mathrm{C}\right.$ por 30 segundos, para desnaturação da dupla fita de DNA; $50^{\circ} \mathrm{C}$ por 30 segundos, para o pareamento dos oligonucleotídeos iniciadores e $72^{\circ} \mathrm{C}$ por 30 segundos de extensão) e um clico a $72^{\circ} \mathrm{C}$ por 7 minutos para extensão final. Os genes de virulência estavam presentes em 18 das 80 amostras analisadas, representando um percentual de 22,5\%, sendo detectados 4 perfis gênicos diferentes. Das 18 amostras, 6 foram positivas para eae $(7,5 \%), 10$ para $s t x l(12,5 \%)$ e 7 para stx2 $(8,8 \%)$. Os resultados fornecem um panorama geral sobre a distribuição dos genes de virulência nas amostras de fezes de galinhas caipiras e podem ser fundamentais para auxiliar futuramente a compreensão da epidemiologia de STEC e EPEC, bem como para observar a capacidade de transmissão de doenças para o homem.

PALAVRAS-CHAVE: GENES DE VIRULÊNCIA. SAÚDE PÚBLICA. DOENÇAS ENTÉRICAS.

AGRADECIMENTOS: FAPESP

ÁREA TEMÁTICA: Epidemiologia

\footnotetext{
${ }^{1}$ Faculdade de Ciências Agrárias e Veterinárias da Universidade Estadual Paulista (UNESP) - Câmpus de Jaboticabal

*mmborzi@gmail.com
} 